\title{
ANALISIS SEKTOR UNGGULAN DI KABUPATEN SLEMAN DAN KABUPATEN GUNUNGKIDUL
}

\author{
Karima Sharazati, Wiwin Priana Primandhana, Mohammad Wahed \\ Universitas Pembangunan Nasional (UPN) Veteran Jawa Timur, Indonesia \\ Email: Ksharazati@gmail.com, wiwinpriana10@gmail.com,dan \\ muhammadwahed124@gmail.com
}

\begin{abstract}
Development of an increasingly complex area in the era of regional autonomy resulting in interstate competition becomes tighter. For the welfare of the community to remain stable and even incresing, local governments must improve the competitiveness of their territory. This study aims to identify economic sectors that will be the priority of regional development based on regional influence, regional specialization, and competitive advantage of economic sector in DIY Province. This study uses to determine the leading sectors in the regional economy of Sleman Regency and Gunungkidul Regency. The data collection techniques used in this study were BPS data and related literature. The sample in this study used 17 economic sectors in GRDP (Gross Regional Domestic Product) of Sleman Regency and Gunungkidul Regency. Technical data analysis in this study using Shift Share analysis, Location Quotient, and Klassen's Typology. Based on the three analysis, it was found that the Accommodation and Food and Drink sectors were the leading sectors in Sleman Regency. And the Other Services sector is the leading sector of Gunungkidul Regency
\end{abstract}

Keywords: gross regional domestic product; shift share (SS); location quotient (LQ); klassen typology

\section{Abstrak}

Pembangunan daerah semakin kompleks pada era otonomi daerah, mengakibatkan persaingan antar daerah menjadi semakin ketat. Agar kesejahteraan masyarakat tetap terjaga dan bahkan semakin meningkat pemerintah daerah harus meningkatkan daya saing wilayahnya. Penelitian ini bertujuan untuk mengindentifikasi sektor-sektor ekonomi yang akan menjadi prioritas pembangunan daerahnya berdasar pengaruh regional, spesialisasi daerah, dan keunggulan daya saing ekonomi sektoral di Provinsi Daerah Istimewa Yogyakarta. Penelitian ini dilakukan untuk mengetahui sektor unggulan dalam perekonomian daerah Kabupaten Sleman dan Kabupaten Gunungkidul. Teknik pengumpulan data yang digunakan dalam penelitian yaitu data BPS dan literature terkait. Sampel dalam penelitian ini menggunakan 17 sektor ekonomi pembentuk PDRB (Produk Domestik Regional Bruto) Kabupaten Sleman dan Kabupaten Gunungkidul. Teknik analisis yang digunakan yaitu menggunakan analisis Shift Share, Location Quotient,Tipologi Klassen. Berdasarkan hasil analisis ditemukan sektor akomodasi

\begin{tabular}{ll}
\hline How to cite: & Sharazati, Karima, Wiwin Priana Primandhana dan Mohammad Wahed (2021) Analisis Sektor \\
& Unggulan Di Kabupaten Sleman Dan Kabupaten Gunungkidul (3)6. https://doi.org/10.36418/syntax- \\
& idea.v3i6.1229 \\
E-ISSN: & 2684-883X \\
Published by: & Ridwan Institute
\end{tabular}


dan makan minum ialah sektor unggulan Kabupaten Sleman dan sektor jasa lainnya adalah sektor unggulan Kabupaten Gunungkidul.

Kata Kunci : produk domestik regional bruto; shift share $(S S)$; location quotient $(L Q)$; Pendahuluan

Dalam rangka mewujudkan keberhasilan pembangunan nasional dibutuhkan peran aktif dari pembangunan daerah. Untuk meningkatkan kesejahteraan dan pembangunan ekonomi pada suatu daerah harus dilakukan dengan pertumbuhan ekonomi yang berkelanjutan (Pratiwi \& Warnaningtyas, 2015). Menurut (Wenda \& Tarore, 2018) pertumbuhan ekonomi adalah tolak ukur adanya pembangunan ekonomi pada suatu wilayah. Menurut (Hadi, 2018) dengan pertumbuhan ekonomi wilayah yang tinggi maka akan diikuti dengan kesejahteraan masyarakatnya yang juga akan ikut meningkat.

Dalam pelaksanaannya wewenang otonomi daerah diharapkan untuk mampu menjalankan pemerintahanya dengan mandiri dalam menentukan kebijakan-kebijakan pembangunan daerah beserta pembiayaan pembangunan yang terjadi pada daerahnya. Adanya kesenjangan antar daerah dan berkembangnya globalisasi mengakibatkan persaingan antar daerah menjadi semakin ketat. Setiap daerah harus mampu meningkatkan daya saing wilayahnya agar kesejahteraan masyarakat semakin meningkat (Basuki \& Mujiraharjo, 2017). Tingkat perkembangan PDRB dapat dijadikan tolak ukur dalam mencapai tujuan menciptakan pembangunan ekonomi menurut (Prishardoyo, 2008). Menurut (Tumangkeng, 2018) salah satu faktor yang berpengaruh terhadap pertumbuhan ekonomi suatu daerah adalah lokasi. Tingkat aksesibilitas atau kemudahan dalam mencapai lokasi ditinjau dari lokasi lain disekitarnya.

Menurut (Pratiwi \& Warnaningtyas, 2015), pertumbuhan ekonomi berkelanjutan adalah kunci utama dalam kesuksesan pembangunan ekonomi daerah. Dikarenakan jumlah penduduk setiap tahunnya bertambah maka kebutuhan ekonomi juga ikut bertambah. Melihat hal ini dibutuhkan penambahan pendapatan setiap tahun melalui peningkatan output (barang dan jasa) atau PDRB pada setiap tahunya. Menurut (Pradana, 2019) adanya pertumbuhan ekonomi membuat geliat iklim usaha semakin terjaga, terjadinya peningkatan pada pendapatan, dan berdampak positif pada indeks pembangunan manusia. Dari penjelasan tersebut maka peneliti ingin menganaslisis sektor unggulan di Kabupaten Sleman dan Kabupaten Gunungkidul. Dari potensi ekonomi dan keadaan wilayah dapat dijadikan dalam penentu pola, strategi dan kebijakan pemerintah (Adyatama, 2018).

Penelitian mengenai sektor unggulan telah dilakukan oleh beberapa peneliti sebelumnya, antara lain (Basuki \& Mujiraharjo, 2017), (Takalumang et al., 2018), (Pradana, 2019), (Rima Prasetya, 2018), (Ibrahim, 2018) menyimpulkan bahwa sektor unggulan yang dimiliki masing-masing daerah mampu menjadi motor penggerak bagi sektor-sektor lain (multiplier effect). Sektor unggulan perekonomian dapat dijadikan tumpuan harapan pembangunan ekonomi. Jika ekspor suatu wilayah ke wilayah lain semakin besar maka pertumbuhan wilayah tersebut juga semakin meningkat (Anonim, 
Analisis Sektor Unggulan Di Kabupaten Sleman dan Kabupaten Gunungkidul.

2005). Dari penjelasan tersebut peneliti ingin menganalisis sektor unggulan di Kabupaten Sleman dan Kabupaten Gunungkidul.

\section{Metode Penelitian}

Penelitian ini dilakukan di Kabupaten Sleman dan Kabupaten Gunungkidul dengan melihat data Produk Domestik Regional Bruto (PDRB) Kabupaten Sleman atas tahun dasar 2010 periode tahun 2015-2019 (Anonim, 2020), Produk Domestik Regional Bruto (PDRB) Kabupaten Gunungkidul atas tahun dasar 2010 periode tahun 2015 2019 (Anonim, 2019b) dan data Produk Domestik Regional Bruto Provinsi Daerah Istimewa Yogyakarta tahun 2015-2019 (Anonim, 2019a). Pembangunan ekonomi pada suatu daerah tidak jauh berbeda dengan pembangunan ekonomi nasional. Namun pada proses pembangunan daerah jauh lebih spesifik menurut Tambunan dalam (Putra, 2019). Data yang berhubungan dengan obyek penelitian disusun untuk selanjutnya diolah dengan menggunakan alat berupa analisis Shift Share, Location Quotient, Tipologi Klassen.

\section{Teknik analisis}

\section{a. Shift Share}

Analisis Shift Share (SS) digunakan dalam mengkaji kinerja sektor ekonomi yang berkembang pada suatu wilayah dengan membandingkan dengan perekonomian di wilayah yang lebih luas. Tehnik analisis ini menyatakan perubahan struktur ekonomi daerah yang berhubungan erat dengan dengan komponen potensi regional yang menggambarkan seberapa besar pengaruh pertumbuhan ekonomi nasional terhadap daerah. Kedua pergeseran proportional yang mengukur besaran kinerja pada suatu sektor tertentu di daerah terhadap sektor yang sama pada wilayah yang lebih luas. Daerah yang didominasi sektor yang lamban maka pertumbuhanya akan berada dibawah tingkat pertumbuhan ekonomi daerah diatasnya (Rima Prasetya, 2018).

Analisis Shift Share dibagi menjadi 3 komponen utama:

1.) PR (Potential Regional)

$P R_{i j}=\left\{Q_{i j}^{0} \frac{Y_{t}}{Y_{0}}-1\right\}$

Bila PR $<{ }^{\Delta Q_{i j}}$ maka pertumbuhan sektor tersebut di kabupaten/kota itu akan mendorong pertumbuhan sektor yang sama di provinsi.

Bila PR > ${ }^{\Delta Q_{i j}}$ maka pertumbuhan sektor tersebut di kabupaten/kota itu akan menghambat pertumbuhan sektor yang sama di provinsi.

2.) PS (Proportional Shift)

$P S_{i j}=\left\{Q_{i}^{0} \frac{Q_{i}^{t}}{Q_{i}^{0}}-\frac{Y_{t}}{Y_{0}}\right\}$

Bila PS > 0 maka sektor tersebut tumbuh lebih cepat dari sektor yang sama di tingkat provinsi. 
Bila PS $<0$ maka sektor tersebut tumbuh lebih lambat dari sektor yang sama di tingkat provinsi.

3.) DS (Differential Shift)

$$
D S_{i j}=\left\{Q_{i j}^{0} \frac{Q_{i j}^{t}}{Q_{i j}^{0}}-\frac{Q_{i}^{t}}{Q_{i}^{0}}\right\}
$$

Bila DS > 0 maka sektor tersebut memiliki pertumbuhan yang lebih cepat dibandingkan sektor yang sama di Kabupaten Sleman / Gunung Kidul atau dengan kata lain sektor tersebut mempunyai keuntungan lokasional yang baik.

Bila DS < 0 maka sektor tersebut memiliki pertumbuhan yang lebih lambat dibandingkan sektor yang sama di Kabupaten Sleman / Gunung Kidul atau dengan kata lain sektor tersebut tidak mempunyai keuntungan lokasional yang baik

Keterangan:

$Y_{t}=$ Total PDRB Provinsi Daerah Istimewa Yogyakarta Periode tahun $\mathrm{t}$

$Y_{0}=$ Total PDRB Provinsi Daerah Istimewa Yogyakarta Periode tahun dasar

$Q_{i}^{t}=$ PDRB Provinsi Daerah Istimewa Yogyakarta sektor i pada tahun t

$Q_{i}^{0}=$ PDRB Provinsi Daerah Istimewa Yogyakarta sektor i pada tahun dasar

$Q_{i}^{t}=$ PDRB Kabupaten Sleman/Kabupaten Gunung Kidul sektor i pada tahun $\mathrm{t}$

$Q_{i}^{0}=$ PDRB Kabupaten Sleman/Kabupaten Gunung Kidul sektor i pada tahun dasar

\section{b. Location Quotient (LQ)}

Analisis LQ digunakan untuk mencari sektor basis dan sektor non basis. Metode ini dilakukan dengan membandingkan nilai suatu sektor di daerah terhadap sektor yang sama di tingkat regional. Tujuanya untuk mengidentifikasi potensi unggulan suatu daerah. Perhitungan analisis LQ menurut Kuncoro,2004 dalam (Hatta, 2019) sebagai berikut :

$$
\mathrm{LQ}=\frac{\mathrm{Si} / \mathrm{S}}{\mathrm{Ni} / \mathrm{N}}
$$

Dimana:

$\mathrm{LQ}=$ Index Location Quotient

$\mathrm{Si}=$ PDRB sektor i di Kabupaten Sleman atau di Kabupaten Gunungkidul

S = PDRB total Kabupaten Sleman atau di Kabupaten Gunungkidul

$\mathrm{Ni}=$ PDRB sektor i di Provinsi DIY

$\mathrm{N}=$ PDRB total Provinsi DIY

Hasil perhitungan yang diperoleh, dapat diartikan dalam dua kategori yaitu: Bila nilai $\mathrm{LQ}<1$, menunjukkan bahwa sektor tersebut bukan sektor basis. Bila LQ > 1 , menunjukkan bahwa sektor tersebut adalah sektor basis. 


\section{c. Tipologi Klassen}

Analisis Typologi Klassen digunakan dengan mengklasifikasikan sektor ekonomi pembentuk PDRB pada suatu daerah. Analisis ini dilakukan guna mengidentifikasi posisi sektor ekonomi dalam PDRB suatu wilayah yang lebih sempit dengan memperhatikan sektor ekonomi pada wilayah yang lebih luas sebagai daerah referensi. Analisis ini dibagi menjadi empat klasifikasi sektor ekonomi beserta karakteristik yang berbeda menurut (Hatta, 2019).

Tabel 1

Klasifikasi Sektor PDRB menurut Tipologi Klasen

\begin{tabular}{ccc}
\hline Laju pertumbuhan & si $>\mathbf{s}$ & si $<\mathbf{s}$ \\
\hline distribusi & $\begin{array}{c}\text { Kuadran I } \\
\text { Sektor maju dan tumbuh } \\
\text { dengan pesat }\end{array}$ & $\begin{array}{c}\text { Kuadran II } \\
\text { Sektor maju tetapi } \\
\text { tertekan }\end{array}$ \\
\hline $\begin{array}{c}\text { Kuadran III } \\
\text { Sektor potensial atau } \\
\text { masih dapat berkembang }\end{array}$ & $\begin{array}{c}\text { Kuadran IV } \\
\text { Sektor relatif tertinggal }\end{array}$ \\
\hline
\end{tabular}

Sumber : Peneliti

\section{Keterangan:}

Ski : Distribusi sektor i terhadap PDRB Kabupaten

Sk : Distribusi sektor i terhadap PDRB Provinsi

$\mathrm{Si} \quad$ : Laju pertumbuhan sektor i ditingkat Kabupaten

$\mathrm{S} \quad$ : Laju pertumbuhan sektor i ditingkat Provinsi

a. Dalam kuadran I berisi sektor dengan laju pertumbuhan dalam PDRB (si) lebih besar dibandingkan laju pertumbuhan sektor yang sama dalam PDRB daerah referensi (s) dan mempunyai nilai distribusi sektor PDRB (ski) lebih besar dibanding distribusi sektor yang sama terhadap PDRB daerah referensi (sk)

b. Dalam kuadran II berisi sektor dengan laju pertumbuhan dalam PDRB (si) lebih kecil daripada laju pertumbuhan sektor yang sama dalam PDRB daerah referensi (s) dan memiliki nilai distribusi sektor terhadao PDRB (ski) lebih besar daripada distribusi sektor tersebut terhadap PDRB daerah referensi (sk).

c. Dalam kuadran III laju pertumbuhan sektor tertentu dalam PDRB (si) lebih besar daripada laju pertumbuhan sektor yang sama dalam PDRB daerah referensi (s) dan mempunyai nilai distribusi sektor terhadap PDRB (ski) yang lebih kecil daripada distribusi sektor yang sama terhadap PDRB daerah referensi (sk).

d. Dalam kuadran IV laju pertumbuhan suatu sektor dalam PDRB (si) lebih kecil daripada laju pertumbuhan sektor yang sama dalam PDRB daerah referensi (s) dan mempunyai nilai distribusi sektor terhadap PDRB (ski) 
lebih kecil daripada distribusi sektor yang sama terhadap PDRB daerah referensi (sk).

\section{Hasil dan Pembahasan}

Dimaksudkan tujuan pembangunan ekonomi tidak hanya untuk meningkatkan pendapatan riil namun juga meningkatkan produktivitas (Setiyaningrum, 2014). Adanya peningkatan produktivitas akan meningkatkan taraf hidup dan mendorong pembangunan ekonomi. Dari perhitungan Shift Share PS untuk melihat cepat atau lambatnya pertumbuhan ekonomi suatu sektor, Shift Share $P R$ untuk melihat apakah sektor ekonomi yang ada mampu mendorong pertumbuhan ekonomi atau akan menghambat pertumbuhan ekonomi, dan Shift Share DS untuk melihat pertumbuhan sektor yang lebih cepat dibandingkan sektor yang sama di Kabupaten atau Provinsi. Maka ditemukan 12 sektor Kabupaten Sleman yang memiliki hasil PS > 0 yaitu sektor industri pengolahan, sektor pengadaan listrik, sektor konstruksi, sektor perdagangan besar dan eceran, reparasi mobil dan sepeda motor, sektor akomodasi makan dan minum, sektor informasi dan komunikasi, sektor jasa keuangan dan asuransi, sektor real estate, sektor jasa perusahaan, sektor jasa pendidikan, sektor jasa kesehatan dan kegiatan sosial, dan yang terakhir adalah sektor jasa lainnya. Untuk Kabupaten Gunungkidul 13 sektor dengan nilai ps > daripada 0 yaitu sektor industri pengolahan, sektor pengadaan listrik dan gas, sektor pengadaan air, pengelolaan sampah, limbah dan daur ulang, sektor konstruksi, sektor perdagangan besar dan eceran, reparasi mobil dan sepeda motor, sektor akomodasi makan dan minum, sektor informasi dan komunikasi, sektor jasa keuangan dan asuransi, sektor real estate, sektor jasa perusahaan, sektor jasa pendidikan, sektor jasa kesehatan dan kegiatan sosial, dan sektor jasa lainnya.

Dari perhitungan Shift Share PR Kabupaten Sleman ditemukan Sektor pengadaan listrik dan gas, sektor konstruksi, sektor akomodasi makan dan minum, dan sektor informasi dan komunikasi. Untuk Kabupaten Gunungkidul yaitu sektor pengadaan listrik dan gas, sektor konstruksi, sektor akomodasi makan dan minum, sektor informasi dan komunikasi, sektor real estate, dan sektor jasa lainnya.

Pada perhitungan Shift Share DS ditemukan pertanian, kehutanan dan perikanan, sektor industri pengolahan, sektor pengadaan listrik dan gas, sektor pengadaan air, pengelolaan sampah, limbah dan daur ulang, sektor perdagangan besar dan eceran, reparasi mobil dan sepeda motor, sektor informasi dan komunikasi, sektor jasa keuangan dan asuransi, sektor real estate, sektor jasa perusahaan, sektor administrasi pemerintah, pertahanan dan jaminan sosial wajib, dan sektor jasa lainnya.

\begin{tabular}{lcccccccc}
\hline \multicolumn{7}{c}{ TABEL SEKTOR UNGGULAN (U) DAN NON UNGGULAN (NU) } \\
KABUPATEN SLEMAN 2015 & $\mathbf{2 0 1 9}$ \\
\multicolumn{1}{c}{ SEKTOR } & $\mathbf{2 0 1 5}$ & $\mathbf{2 0 1 6}$ & $\mathbf{2 0 1 7}$ & $\mathbf{2 0 1 8}$ & $\mathbf{2 0 1 9}$ & $\begin{array}{c}\text { Rata - } \\
\text { rata }\end{array}$ & Ket. \\
\hline $\begin{array}{l}\text { Pertanian, Kehutanan dan } \\
\text { Perikanan }\end{array}$ & 0,78 & 0,77 & 0,76 & 0,76 & 0,76 & 0,77 & $\mathrm{Nb}$ \\
\hline Pertambangan dan Penggalian & 0,73 & 0,72 & 0,70 & 0,69 & 0,71 & 0,71 & $\mathrm{Nb}$ \\
\hline Industri Pengolahan & 1,00 & 0,99 & 0,99 & 1,00 & 1,00 & 1,00 & $\mathrm{~B}$ \\
\hline
\end{tabular}




\begin{tabular}{|c|c|c|c|c|c|c|c|}
\hline \multicolumn{8}{|c|}{$\begin{array}{l}\text { TABEL SEKTOR UNGGULAN (U) DAN NON UNGGULAN (NU) } \\
\text { KABUPATEN SLEMAN } 2015 \text { - } 2019\end{array}$} \\
\hline SEKTOR & 2015 & 2016 & 2017 & 2018 & 2019 & $\begin{array}{c}\text { Rata - } \\
\text { rata }\end{array}$ & Ket. \\
\hline Pengadaan Listrik dan Gas & 0,80 & 0,81 & 0,81 & 0,80 & 0,80 & 0,80 & $\mathrm{Nb}$ \\
\hline $\begin{array}{l}\text { Pengadaan air, Pengelolaan } \\
\text { sampah, Limbah dan Daur } \\
\text { Ulang }\end{array}$ & 0,47 & 0,47 & 0,46 & 0,46 & 0,46 & 0,46 & $\mathrm{Nb}$ \\
\hline Konstruksi & 1,18 & 1,17 & 1,17 & 1,17 & 1,15 & 1,17 & $\mathrm{~B}$ \\
\hline $\begin{array}{l}\text { Perdagangan Besar dan Eceran, } \\
\text { Reparasi Mobil dan Sepeda } \\
\text { Motor }\end{array}$ & 0,91 & 0,92 & 0,91 & 0,91 & 0,91 & 0,91 & $\mathrm{Nb}$ \\
\hline Transportasi dan pergudangan & 1,16 & 1,19 & 1,20 & 1,21 & 1,15 & 1,18 & $\mathrm{~B}$ \\
\hline Akomodasi dan Makan Minum & 1,04 & 1,04 & 1,03 & 1,03 & 1,04 & 1,04 & $\mathrm{~B}$ \\
\hline Informasi dan Komunikasi & 0,97 & 0,97 & 0,97 & 0,97 & 0,97 & 0,97 & $\mathrm{Nb}$ \\
\hline Jasa Keuangan dan asuransi & 0,82 & 0,82 & 0,82 & 0,82 & 0,83 & 0,82 & $\mathrm{Nb}$ \\
\hline Real Estate & 1,14 & 1,14 & 1,14 & 1,13 & 1,13 & 1,14 & $\mathrm{~B}$ \\
\hline Jasa Perusahaan & 1,65 & 1,65 & 1,64 & 1,64 & 1,65 & 1,65 & $\mathrm{~B}$ \\
\hline $\begin{array}{l}\text { Administrasi Pemerintah, } \\
\text { Pertahanan dan Jaminan Sosial } \\
\text { Wajib }\end{array}$ & 0,80 & 0,80 & 0,80 & 0,80 & 0,80 & 0,80 & $\mathrm{Nb}$ \\
\hline Jasa Pendidikan & 1,15 & 1,16 & 1,16 & 1,16 & 1,16 & 1,16 & $\mathrm{~B}$ \\
\hline $\begin{array}{l}\text { Jasa Kesehatan dan Kegiatan } \\
\text { sosial }\end{array}$ & 0,93 & 0,93 & 0,93 & 0,92 & 0,93 & 0,93 & $\mathrm{Nb}$ \\
\hline Jasa lainnya & 0,87 & 0,86 & 0,86 & 0,85 & 0,84 & 0,86 & $\mathrm{Nb}$ \\
\hline
\end{tabular}

Sumber : Penulis

Dari perhitungan LQ Kabupaten Sleman didapati beberapa sektor yang menjadi sektor basis wilayah tersebut antara lain industri pengolahan, sektor konstruksi, sektor transportasi dan pergudangan, sektor akomodasi dan makan minum, sektor real estate, sektor jasa perusahaan,dan sektor jasa pendidikan.

\begin{tabular}{|c|c|c|c|c|c|c|c|}
\hline \multicolumn{8}{|c|}{$\begin{array}{l}\text { TABEL SEKTOR UNGGULAN (U) DAN NON UNGGULAN (NU) } \\
\text { KABUPATEN GUNUNGKIDUL } 2015-2019\end{array}$} \\
\hline SEKTOR & 2015 & 2016 & 2017 & 2018 & 2019 & $\begin{array}{c}\text { Rata }- \\
\text { rata }\end{array}$ & $\mathbf{K e}$ \\
\hline Pertanian, Kehutanan dan Perikanan & 2,50 & 2,52 & 2,53 & 2,55 & 2,58 & 2,54 & $\mathrm{~b}$ \\
\hline Pertambangan dan Penggalian & 2,56 & 2,58 & 2,57 & 2,46 & 2,48 & 2,53 & $\mathrm{~b}$ \\
\hline Industri Pengolahan & 0,72 & 0,73 & 0,74 & 0,74 & 0,76 & 0,74 & $\mathrm{nb}$ \\
\hline Pengadaan Listrik dan Gas & 0,65 & 0,65 & 0,66 & 0,67 & 0,67 & 0,66 & $\mathrm{nb}$ \\
\hline $\begin{array}{l}\text { Pengadaan air, Pengelolaan sampah, } \\
\text { Limbah dan Daur Ulang }\end{array}$ & 1,57 & 1,57 & 1,58 & 1,59 & 1,64 & 1,59 & $\mathrm{~b}$ \\
\hline Konstruksi & 0,99 & 0,99 & 1,00 & 0,96 & 0,92 & 0,97 & $\mathrm{nb}$ \\
\hline $\begin{array}{l}\text { Perdagangan Besar dan Eceran, } \\
\text { Reparasi Mobil dan Sepeda Motor }\end{array}$ & 1,12 & 1,13 & 1,14 & 1,15 & 1,17 & 1,14 & $\mathrm{~b}$ \\
\hline Transportasi dan pergudangan & 0,96 & 0,95 & 0,95 & 0,93 & 0,97 & 0,95 & $\mathrm{nb}$ \\
\hline Akomodasi dan Makan Minum & 0,61 & 0,61 & 0,61 & 0,61 & 0,61 & 0,61 & $\mathrm{nb}$ \\
\hline Informasi dan Komunikasi & 0,85 & 0,86 & 0,86 & 0,88 & 0,90 & 0,87 & $\mathrm{nb}$ \\
\hline Jasa Keuangan dan asuransi & 0,59 & 0,58 & 0,57 & 0,59 & 0,60 & 0,59 & $\mathrm{nb}$ \\
\hline Real Estate & 0,48 & 0,49 & 0,50 & 0,51 & 0,52 & 0,50 & $\mathrm{nb}$ \\
\hline Jasa Perusahaan & 0,43 & 0,43 & 0,44 & 0,44 & 0,44 & 0,44 & $\mathrm{nb}$ \\
\hline Administrasi Pemerintah, & 1,17 & 1,17 & 1,18 & 1,19 & 1,21 & 1,18 & $\mathrm{~b}$ \\
\hline
\end{tabular}




\begin{tabular}{|c|c|c|c|c|c|c|c|}
\hline \multicolumn{8}{|c|}{$\begin{array}{l}\text { TABEL SEKTOR UNGGULAN (U) DAN NON UNGGULAN (NU) } \\
\text { KABUPATEN GUNUNGKIDUL 2015 - } 2019\end{array}$} \\
\hline $\begin{array}{l}\text { Pertahanan dan Jaminan Sosial } \\
\text { Wajib }\end{array}$ & & & & & & & \\
\hline Jasa Pendidikan & 0,75 & 0,75 & 0,76 & 0,76 & 0,77 & 0,76 & $\mathrm{nb}$ \\
\hline Jasa Kesehatan dan Kegiatan sosial & 0,81 & 0,81 & 0,82 & 0,82 & 0,83 & 0,82 & $\mathrm{nb}$ \\
\hline Jasa lainnya & 1,31 & 1,34 & 1,35 & 1,37 & 1,39 & 1,35 & $\mathrm{~b}$ \\
\hline
\end{tabular}

Sumber : Penulis

Diketahui Kabupaten Gunungkidul memiliki 6 sektor basis antara lain sektor pertanian, kehutanan dan perikanan, sektor pertambangan dan penggalian, sektor pengadaan air, pengelolaan sampah, limbah dan daur ulang, sektor perdagangan besar dan eceran, reparasi mobil dan sepeda motor, sektor administrasi pemerintah, pertahanan dan jaminan sosial wajib dan sektor jasa lainya. dari perhitungan anaisis Tipologi Klassen Kabupaten Sleman sebagai berikut

Tipologi Klassen Kabupaten Sleman dan Kabupaten Gunungkidul

\begin{tabular}{cll}
\hline Analisis & Kabupaten Sleman 2015-2019 & \multicolumn{1}{c}{ Kabupaten Gunungkidul2015-2019 } \\
\hline Tipologi & Kuadran I & Kuadran I \\
Klassen & Sektor Akomodasi Makan dan & Sektor Pertanian, Kehutanan dan Perikanan \\
& Minum & Sektor Industri Pengolahan \\
& Sektor Real Estate & Sektor Pengadaan air, Pengelolaan sampah, \\
& Sektor Jasa Pendidikan & Limbah dan Daur Ulang \\
& Sektor Perdagangan Besar dan Eceran, \\
& Kuadran II & Reparasi Mobil dan Sepeda Motor \\
& Sektor Konstruksi & Sektor Jasa Lainnya \\
& Sektor Transportasi dan pergudangan & \\
Sektor Administrasi Pemerintah, & Kuadran II \\
& Pertahanan dan Jaminan Sosial Wajib & Sektor Pertambangan dan Penggalian \\
& Sektor Administrasi Pemerintah, Pertahanan \\
& Kuadran III & dan Jaminan Sosial Wajib \\
Sektor Industri Pengolahan & \\
Sektor Pengadaan Listrik dan Gas & Kuadran III \\
Sektor Perdagangan Besar dan & Sektor Pengadaan Listrik dan Gas \\
Eceran, Reparasi Mobil dan Sepeda & Sektor Informasi dan Komunikasi \\
Motor & Sektor Jasa Keuangan dan Asuransi \\
Sektor Informasi dan Komunikasi & Sektor Real Estate \\
Sektor Jasa Keuangan dan Asuransi & Sektor Jasa Perusahaan \\
Sektor Jasa Perusahaan & Sektor Jasa Pendidikan \\
Sektor Jasa Kesehatan dan Kegiatan & \\
Sosial & Kuadran IV \\
& Sektor Konstruksi \\
Kuadran IV & Sektor Transportasi dan Pergudangan \\
Sektor Pertanian, Kehutanan dan & Sektor Akomodasi Makan dan Minum \\
Perikanan & Sektor Jasa Kesehatan dan Kegiatan Sosial \\
Sektor Pertambangan dan Galian & \\
Sektor Pengadaan air, Pengelolaan & \\
sampah, Limbah dan Daur Ulang & \\
Sektor Jasa Lainnya & \\
&
\end{tabular}

Sumber : Penulis 
Analisis Sektor Unggulan Di Kabupaten Sleman dan Kabupaten Gunungkidul.

\section{Kesimpulan}

Berdasarkan hasil analisis yang telah dilakukan penulis dapat disimpulkan bahwa; Pertama, Sektor yang tumbuh relatif cepat ditingkat Provinsi, Pada analisis Shift Share PS Kabupaten Sleman terdapat 12 sektor yang tumbuh cepat dibandingkan sektor yang sama pada Provinsi antara lain : sektor industri pengolahan, sektor pengadaan listrik dan gas, sektor konstruksi, sektor perdagangan besar dan eceran, reparasi mobil dan sepeda motor, sektor akomodasi dan makan minum, sektor informasi dan komunikasi, sektor jasa keuangan dan asuransi, sektor real estate, sektor jasa perusahaan, sektor jasa pendidikan, sektor jasa kesehatan dan kegiatan sosial, sektor jasa lainnya. Pada analisis Shift Share PS Kabupaten Gunungkidul terdapat 13 sektor yang tumbuh cepat dibandingkan sektor yang sama pada Provinsi, antara lain sektor industri pengolahan, sektor pengadaan listrik dan gas, sektor pengadaan air, pengelolaan sampah, limbah dan daur ulang, sektor konstruksi, sektor perdagangan besar dan eceran, reparasi mobil dan sepeda motor, sektor akomodasi dan makan minum, sektor informasi dan komunikasi, sektor jasa keuangan dan asuransi, sektor real estate, sektor jasa perusahaan, sektor jasa pendidikan, sektor jasa kesehatan dan kegiatan sosial, sektor jasa lainnya. Kedua, Sektor yang mampu mendorong pertumbuhan sektor yang sama pada Provinsi. Perhitungan Shift Share PR Kabupaten Sleman terdapat 4 (empat) sektor yang mampu mendorong pertumbuhan sektor yang sama pada provinsi yaitu sektor pengadaan listrik dan gas, sektor konstruksi, sektor akomodasi dan makan minum, sektor informasi dan komunikasi. Pada perhitungan Shift Share PR Kabupaten Gunungkidul terdapat 6 sektor yang mampu mendorong pertumbuhan sektor yang sama pada provinsi yaitu sektor pengadaan listrik dan gas, sektor konstruksi, sektor akomodasi dan makan minum, sektor informasi dan komunikasi, sektor real estate, dan sektor jasa lainnya. Ketiga, Sektor yang memiliki keuntungan lokasional dan perhitungan Shift Share DS Kabupaten Sleman terdapat 7 sektor dengan memiliki keuntungan lokasional. Sektor tersebut yaitu sektor industri pengolahan, sektor pengadaan listrik dan gas, sektor akomodasi dan makan minum, sektor informasi dan komunikasi, sektor jasa keuangan dan asuransi, sektor jasa pendidikan, sektor jasa kesehatan dan kegiatan sosial. Dan perhitungan Shift Share DS Kabupaten Gunungkidul terdapat 11 sektor dengan memiliki keuntungan lokasional. Sektor tersebut yaitu sektor pertanian, kehutanan dan perikanan, sektor industri pengolahan, sektor pengadaan listrik dan gas, sektor pengadaan air, pengelolaan sampah, limbah dan daur ulang, sektor perdagangan besar dan eceran, reparasi mobil dan sepeda motor, sektor informasi dan komunikasi, sektor jasa keuangan dan asuransi, sektor real estate, sektor jasa perusahaan, sektor administrasi pemerintah, pertahanan dan jaminan sosial wajib, sektor jasa lainnya. Keempat, sektor basis pada perhitungan analisis location quotient Kabupaten Sleman dapat diketahui bahwa Kabupaten Sleman memiliki 7 sektor basis diantaranya sektor industri pengolahan, sektor transportasi dan pergudangan, sektor industri pengolahan, sektor akomodasi dan makan minum, sektor real estate, sektor jasa perusahaan, dan sktor jasa pendidikan. Kemudian untuk Kabupaten Gunungkidul memiliki 6 sektor basis antara lain sektor pertanian, kehutanan dan perikanan, sektor pertambangan dan 
penggalian, sektor pengadaan air, pengelolaan sampah, limbah dan daur ulang, sektor perdagangan besar dan eceran, reparasi mobil dan sepeda motor, sektor administrasi pemerintah, pertahanan dan jaminan sosial wajib, dan sektor jasa lainya. (5.) Tipologi Klassen, pada analisis tipologi klassen Kabupaten Sleman terdapat 3 sektor pada kuadran I yaitu sektor akomodasi makan dan minum, Sektor Real Estate dan Sektor Jasa Pendidikan. Pada Kuadran II terdapat tiga sektor dengan kategori sektor maju tetapi tertekan yaitu sektor konstruksi, kemudian sektor transportasi dan pergudangan, dan sektor administrasi pemerintah, pertahanan dan jaminan sosial wajib. pada kuadran iii ditemukan tujuh sektor potensial atau masih dapat berkembang yaitu sektor industri pengolahan, sektor pengadaan listrik dan gas, sektor perdagangan besar dan eceran, reparasi mobil dan sepeda motor, sektor informasi dan komunikasi, sektor jasa keuangan dan asuransi, kemudian sektor jasa perusahaan, dan sektor jasa kesehatan dan kegiatan sosial. pada ada kuadran iv atau termasuk sektor relatif tertinggal terdapat empat sektor antara lain sektor pertanian, kehutanan dan perikanan, sektor pertambangan dan galian, sektor pengadaan air, pengelolaan sampah, limbah dan daur ulang, dan sektor jasa lainnya untuk tipologi klassen Kabupaten Gunungkidul kuadran I terdapat sektor pertanian, kehutanan dan perikanan, sektor industri pengolahan, sektor pengadaan air, pengelolaan sampah, limbah dan daur ulang, sektor perdagangan besar dan eceran, reparasi mobil dan sepeda motor, dan sektor jasa lainnya. kuadran ii atau sektor maju tetapi tertekan terdapat dua sektor yaitu sektor pertambangan dan penggalian dan sektor administrasi pemerintah, pertahanan dan jaminan sosial wajib. kuadran iii terdapat enam sektor potensial atau masih dapat berkembang antara lain sektor pengadaan listrik dan gas, sektor informasi dan komunikasi, sektor jasa keuangan dan asuransi, sektor real estate, kemudian sektor jasa perusahaan, dan sektor jasa pendidikan. kuadran iv terdapat empat sektor yaitu sektor konstruksi, sektor transportasi dan pergudangan, kemudian sektor akomodasi makan dan minum, dan sektor jasa kesehatan dan kegiatan sosial. dari hasil analisis tujuh belas sektor dalam PDRB kabupaten sleman dan Kabupaten Gunungkidul dapat kita simpulkan bahwa sektor akomodasi dan makan minum ialah sektor unggulan yang dimiliki Kabupaten Sleman. Kemudian sektor unggulan yang dimiliki Kabupaten Gunungkidul ialah sektor Jasa Lainya. Hasil penelitian menunjukan bahwa sektor - sektor tersebut merupakan sektor dengan pertumbuhan relatif cepat dalam mendorong pertumbuhan ekonomi dan memiliki keuntungan lokasional. Sektor - sektor tersebut juga merupakan sektor basis dan memiliki daya saing yang kuat. Diharapkan kontribusi dari sektor unggulan ini akan mampu mendorong pertumbuhan ekonomi dan memberikan harapan pembangunan ekonomi. 
Analisis Sektor Unggulan Di Kabupaten Sleman dan Kabupaten Gunungkidul.

\section{BIBLIOGRAFI}

Adyatama, M. R. (2018). Analisis Struktur Ekonomi Dan Sektor Basis Di Kota Palu Tahun 2012-2016 Skripsi. 1-58.Google Scholar

Anonim. (2005). Landasan Teoritis dan Fakta Empiris, Departemen Pertanian. www.deptan.go.id/konsep/landasan.htm.

Anonim. (2019a). Berita Resmi Statistik DIY. Bps.Go.Id.

Anonim. (2019b). PDRB Gunungkidul. http://publications.lib.chalmers.se/records/fulltext /245180/245180.pdf\%0Ahttps://hdl.handle.net/20.500.12380/245180\%0Ahttp://dx.d oi.org/10.1016/j.jsames.2011.03.003\%0Ahttps://doi.org/10.1016/j.gr.2017.08.001\% 0Ahttp://dx.doi.org/10.1016/j.precamres.2014.12.

Anonim. (2020). Kabupaten Sleman Dalam Angka 2020. In BPS Kabupaten Sleman.

Basuki, M., \& Mujiraharjo, F. N. (2017). Analisis Sektor Unggulan Kabupaten Sleman dengan Metode Shift Share dan Location Quotient. Jurnal Sains, Teknologi Dan Industri, 15(1), 52-60. Google Scholar

Hadi, M. F. (2018). Analisis Penentuan Sektor Unggulan Dalam Penyerapan Tenaga Kerja di Kabupaten Indragiri Hulu; Pendekatan Tipologi Klassen. Jurnal Akuntansi \& Ekonomika, 8(2), 198-208. Google Scholar

Hatta, M. (2019). Sidenreng Rappang Analysis Potential of The Leading Sectors in The Economy of Sidenreng Rappang. 2, 120-133. Google Scholar

Ibrahim, I. (2018). Analisis Potensi Sektor Ekonomi Dalam Upaya Peningkatan Pertumbuhan Ekonomi (Studi Empiris Pada Kabupaten dan Kota di Provinsi Gorontalo tahun 2012-2016). Gorontalo Development Review. Google Scholar

Pradana, R. S. (2019). Analisis Prioritas Pembangunan Daerah Berdasarkan Pengaruh Regional, Spesialisasi Daerah, Dan Keunggulan Kompetitif Ekonomi Sektoral Di Kabupaten Aceh Jaya. Jurnal Litbang Sukowati: Media Penelitian Dan Pengembangan. Google Scholar

Pratiwi, D., \& Warnaningtyas, H. (2015). Analisis Strategi Pembangunan Wilayah Kabupaten Madiun Melalui Sektor Unggulan. Jurnal Ekomaks, 4(2), 1-14. http://unmermadiun.ac.id/ejurnal/index.php/ekomaks/article/view/60 Google Scholar

Prishardoyo, B. (2008). Analisis Tingkat Pertumbuhan Ekonomi Dan Potensi Ekonomi Terhadap Produk Domestik Regional Bruto (Pdrb) Kabupaten Pati Tahun 20002005. Analisis Tingkat Pertumbuhan Ekonomi Dan Potensi Ekonomi Terhadap Produk Domestik Regional Bruto (Pdrb) Kabupaten Pati Tahun 2000-2005, 1(1), 1-9. 
Putra, K. B. E. (2019). Analisis Sektor Basis Ekonomi Terhadap Laju Pertumbuhan Ekonomi Di Kota Surabaya Tahun 2013-2016. Fleps 2019 - Ieee International Conference on Flexible and Printable Sensors and Systems, Proceedings. Google Scholar

Rima Prasetya, E. (2018). Analisis Sektor Unggulan Perekonomian Di Kabupaten Bogor. Scientific Journal of Reflection, 1(4), 1-10. Google Scholar

Setiyaningrum, A. (2014). Sektor Ekonomi Potensial Sebagai Upaya Peningkatan Produk Domestik Regional Bruto Kabupaten KudusA. Jurnal Administrasi Publik Mahasiswa Universitas Brawijaya, 2(4), 680-686. Google Scholar

Takalumang, V. Y., Rumate, V. A., Lapian, A. L. C. P., Pembangunan, J. E., Ekonomi, F., Sam, U., \& Takalumang, V. (2018). Analisis Sektor Ekonomi Unggulan Dalam Mendorong Pertumbuhan Ekonomi Kabupaten/Kepulauan Sangihe. Jurnal Berkala Ilmiah Efisiensi, 18(01), 1-12. Google Scholar

Tumangkeng, S. (2018). Analisis Potensi Ekonomi Di Sektor Dan Sub Sektor Pertanian, Kehutanan Dan Perikanan Kota Tomohon. Jurnal Berkala Ilmiah Efisiensi. Google Scholar

Wenda, E., \& Tarore, M. L. G. (2018). Peranan Sektor Unggulan Terhadap Perekonomian Di Kabupaten Jayawijaya. 14, 263-270. Google Scholar

\section{Copyright holder :}

Karima Sharazati, Wiwin Priana Primandhana dan Mohammad Wahed (2021)

First publication right :

Jurnal Syntax Idea

This article is licensed under: 